\title{
Rebecca Yearling. Ben Jonson, John Marston and Early Modern Drama: Satire and the Audience. Basingstoke: Palgrave, 2016. Pp 223.
}

JOSÉ A. PÉREZ DÍEZ

University of Leeds

Yearling's book is a much-welcome contribution to Marstonian scholarship, and a valuable addition to a comparatively thin corpus of monographic studies of his work. The primary purpose of the book is to reassess John Marston's status as one of the major English playwrights of the turn of the seventeenth century and to analyse why he is 'such a problematic dramatist' (3). Yearling addresses this question systematically through an examination of the use of satirical techniques in the plays, with particular attention to Marston's ambivalent relationship with Ben Jonson's work. The title oddly implies that Jonson is the first focus of the study, when Marston is clearly the core of the discussion. The scope of the book purposefully excludes Eastward Ho!, the only collaboration between the two dramatists (plus Chapman), on the grounds that its stylistic unity, and the difficulty of knowing which of the three plotted the play, make it unhelpful to draw a comparison between their contrasting use of satire. The other omission is The Insatiate Countess, which Marston plotted and perhaps partially drafted, but whose final shape is due to William Barksted and Lewis Machin.

The heavy focus on audience response to performance, as declared in the book's prologue, is useful and productive, though one may wonder whether some of Yearling's assumptions go beyond what she can actually justify. For example, she states that she has 'decided to assume that the plays in print at least broadly reflect how they appeared in their original productions' $(175,22 \mathrm{n})$, which is an understandable perspective, but a bold claim nonetheless. Further, in chapter 1, she claims that 'Paratexts indicate the kind of relationship that the playwright wants to establish between himself and his audience' (20), which is again problematic, both in terms of the intentional purpose attributed to them, and in the fact that the term 'paratext' here denotes solely dramatic inductions, prologues, and epilogues meant to be performed, excluding non-dramatic printed materials such as dedications, arguments, and descriptive lists of characters. As such, the confusion between what the printed playbooks showed and what they might reveal of the original performances endures. Her interpretation of these dramatic 'paratexts', taking for granted that they were always performed on the margins of these plays, also overlooks the issue of how detachable prologues and epilogues were in the period, as we do have evidence that they were quite frequently 
cut, adapted, rewritten, or reassigned to other plays without authorial consent (the many prologues and epilogues in the Fletcher canon being a case in point). Finally, throughout the book Yearling usually assumes an unclearly defined hypothetical audience: for example, statements such as '[Marston] typically leaves his spectators confused and unsettled rather than enlightened' pose the question of who that imagined audience is (120): the original English spectators in early modern playhouses taken as a homogenous entity, potential modern audiences in the theatre, or just a general readership who may try to visualise these performances? The distinction is far from trivial.

The rest of chapter 1 performs an analysis of how Jonson and Marston approached their theatre audiences as declared in the 'paratexts'. In particular, Yearling examines the attitudes of various characters in Marston - the Duke in What You Will and, especially, Doricus in Histriomastix - to trace why his supposed attitude to his audiences in inductions, prologues, and epilogues seems to be less belligerent than Jonson's. This question poses additional problems such as trying to identify the author's views through an examination of dramatic personas — in those paratextual moments and in the dramas themselves - who are tentatively taken to be 'a stand-in for Marston himself' (29). The book's fixation with disentangling Marston's reasons for writing these knotty, difficult plays creations that, as Yearling suggests, are perhaps deliberately obscure and resistant to critical interpretation - is evocative and even fascinating, but I do not think that her conclusions are entirely persuasive. Ultimately, I still wonder whether trying to reveal Marston's or Jonson's hidden 'intentions' is all that relevant to the study of these plays in their cultural and dramatic context.

Chapter 2 traces the contrasting ways in which Marston and Jonson use satire and satirical characters. Starting with a brief survey of Marston's early verse satires, Yearling usefully traces the evolution and general lack of plot agency of Marstonian satirists such as Felice in Antonio and Mellida, Ned Planet in Jack Drum's Entertainment, Chrisoganus in Histriomastix, and, to some extent, Malevole in The Malcontent. In this analysis the book is at its strongest, demonstrating that the a-satirical, uncensorious intentions expressed in some of the epilogues and prologues are contradicted by Marston's ethical preoccupations. Chapter 3 explores some of those issues further, focusing on a chronological examination of the theme of audience provocation in the plays. This chronological examination is, unfortunately, dependent on somewhat outdated scholarship. For example, Yearling, quoting Philip J. Finkelpearl (in 1969), suggests that Histriomastix 'may be Marston's first dramatic work' (28), giving 'c. 1598' as the date, when Martin Wiggins has established that it could not have been written before 1600 , and may 
therefore post-date Jack Drum's Entertainment, the Antonio plays, and What You Will. ${ }^{1}$ Likewise, The Fawn is categorically said to be a '1604 comedy' (37), when it could have been written any time between 1603 and 1606, with a Wiggins 'Best Guess' in $1605 .^{2}$ These imprecisions are not in themselves an insurmountable problem for chapter 3, in which Marston's 'major' plays are discussed 'in roughly chronological order' (10), but pose a fundamental challenge for chapter 2 , which discusses only the 'early' plays 'from around 1598 to 1603 ' (10). The difficulty is to decide which plays are included in that category, and whether 1603 and the accession of James I constitutes a fundamental shift in Marston's career that divides his plays into two periods, his six 'early' Elizabethan plays and his five 'major' Jacobean ones, but Yearling does not make that case.

Yearling's main argument in chapter 3 is that 'Marston adopts tonal, moral, and generic inconsistency as a satiric and educational device throughout his drama' (68), assigning an intentional drive to what critics have traditionally condemned as the supposed chaotic craftsmanship of his work. She then embarks on a perceptive and useful analysis of how Marston's plays subvert his audience's expectations, keeping them 'unsettled and insecure' (69), and how they use theatrical conventions 'only to draw attention to them as conventions' (73), elaborating on Alexander Leggatt's claim that Marston is the most metatheatrical of all English Renaissance dramatists. In what is, by far, the most engaging and productive part of the book, she analyses in sequence the remainder of the Marstonian canon, tracing the evolution of his dramatic technique from Jack Drum's Entertainment to What You Will, Antonio and Mellida, Antonio's Revenge, The Malcontent, The Fawn, The Dutch Courtesan, and Sophonisba, the last play completed by Marston before he took holy orders. The chapter finishes with a brief account of the theatrical reception of the plays, rightfully lamenting the scarcity of professional revivals of Marston's plays since 1642, apart from The Malcontent. In a footnote we are told that some of them may have been revived 'by amateur dramatic societies ... but if this is the case, I have been unable to find any other accounts of them' (191); it is a pity that Yearling is apparently unaware of the influential and high-profile productions of The Dutch Courtesan in Stratford-upon-Avon by Edward's Boys (directed by Perry Mills, 2008) and at the University of York (dir. by Michael Cordner, 2013, documented at http://dutchcourtesan.co.uk), and Antonio's Revenge in another impressive production by Edward's Boys (dir. by Mills, 2011), not to mention the more recent Jack Drum's Entertainment with the Young Actors Company (dir. by Sam Plumb, 2016), presumably too late for this book. Some of these productions, available on DVD and online, may have illuminated some of Yearling's performance interpretations with respect to modern audience response, 
and particularly her views on the effects produced by boy actors in performance, as summarised in the appendix.

Finally, chapter 4 returns to the exploration of the connection between Marston and Jonson, arguing that Marston's influence on Jonson can be felt in the latter's 'mid-period' works - Sejanus, Volpone, Epicene, The Alchemist and Bartholomew Fair - in terms of 'dramatic technique and in spirit' (131). This argument includes an examination of Jonson's experiments 'in genre and the subversion of audience expectations' in those plays (142). Ultimately, Yearling acknowledges the impossibility of knowing 'quite how much Jonson's new direction after the comical satires was directly influenced by Marston's work' (157), but hers is a bold suggestion inviting further study.

Despite its structural and methodological challenges, Yearling has produced a summa Marstoniana that recalls and responds to the received scholarship on the playwright, offering an interesting reinterpretation of some of his preoccupations as a dramatist. By comparison the Jonsonian focus seems slightly ancillary, and the book remains at its strongest when Marston is at its centre.

\section{Notes}

1 Martin Wiggins, British Drama 1533-1642: A Catalogue, 10 vols (Oxford, 201218), 4.357 (entry 1314).

2 Ibid, 5.175 (entry 1455). 